\title{
今spew Disease Reports \\ First report of potato blackleg and soft rot caused by Pectobacterium wasabiae in Turkey
}

\author{
M. Ozturk ${ }^{1}$, H.M. Aksoy ${ }^{1}$, S. Ozturk ${ }^{1}$, M. Potrykus ${ }^{2}$ and E. Lojkowska ${ }^{2}$
}

${ }^{1}$ Department of Plant Protection, Faculty of Agriculture, Ondokuz Mayis University, 55200, Samsun, Turkey; ${ }^{2}$ Department of Biotechnology, Intercollegiate Faculty of Biotechnology (IFB), University of Gdansk and Medical University of Gdansk, 80-309 Gdansk, Poland

*E-mail: muratzm66@gmail.com

Received: 01 Aug 2016. Published: 11 Oct 2016. Keywords: bacterial plant disease, Erwinia, Enterobacteria, recA gene

In 2015, blackleg symptoms were observed in potato (Solanum tuberosum) cvs. Agria, Elfe, Granola and Jelly in Yozgat province (Sorgun town) in the Central Anatolian Region of Turkey. Disease incidence varied from $5-20 \%$. Seventeen infected stem and tuber samples each from nine commercial potato fields were collected, homogenised and plated on nutrient agar medium. After $24 \mathrm{~h}$ incubation at $28^{\circ} \mathrm{C}$ bacteria were transferred to Luria broth agar or crystal violet pectate medium (CVP) plates and incubated for $24 \mathrm{~h}$ at $28^{\circ} \mathrm{C}$. Identification of bacteria forming cavities on CVP medium and capable of causing potato tuber maceration in whole tuber assay (Potrykus et al., 2016) was accomplished with $\mathrm{Y} 1 / \mathrm{Y} 2$ primers specific for Pectobacterium (Darasse et al., 1994), Y45/Y46 primers specific for $P$. atrosepticum (Frechon et al., 1998), and EXPCCF/R primers designed for both $P$. carotovorum subsp. carotovorum and $P$. wasabiae (Kang et al., 2003). Six strains which yielded positive results with EXPCCF/R primers were further tested with PhF/R primers (De Boer et al., 2012) for the identification of $P$. wasabiae; two of these strains isolated from tubers (cv. Jelly) yielded an amplicon characteristic for $P$. wasabiae. BLAST analysis of the recA gene sequence from one of these strains (YS18Y5; GenBank Accession No. KX548226) showed 100\% identity to the sequence of recA of $P$. wasabiae strain SCC3193. Phylogenetic analysis based on $r e c A$ gene sequences (Waleron et al., 2013) available in GenBank was performed by the maximum likelihood method, and served as further confirmation that strain YS18Y5 belongs to $P$. wasabiae (Fig. 1).

Strain YS18Y5 is a motile, oxidase-negative, facultative anaerobe growing on $5 \% \mathrm{NaCl}$ (aq., w/v), capable of utilising lactose, D-trehalose, Dcellobiose, unable to use maltose and D-sorbitol as carbon sources and unable to grow at $39^{\circ} \mathrm{C}$. The tuber maceration test indicated that strain YS18Y5 (applied as a suspension of 5 on the McFarland scale) is able to cause soft rot symptoms on potato tuber tissue using a whole tuber assay (Fig. 2). To the best of our knowledge this represents the first report on the occurrence of $P$. wasabiae in Turkey.

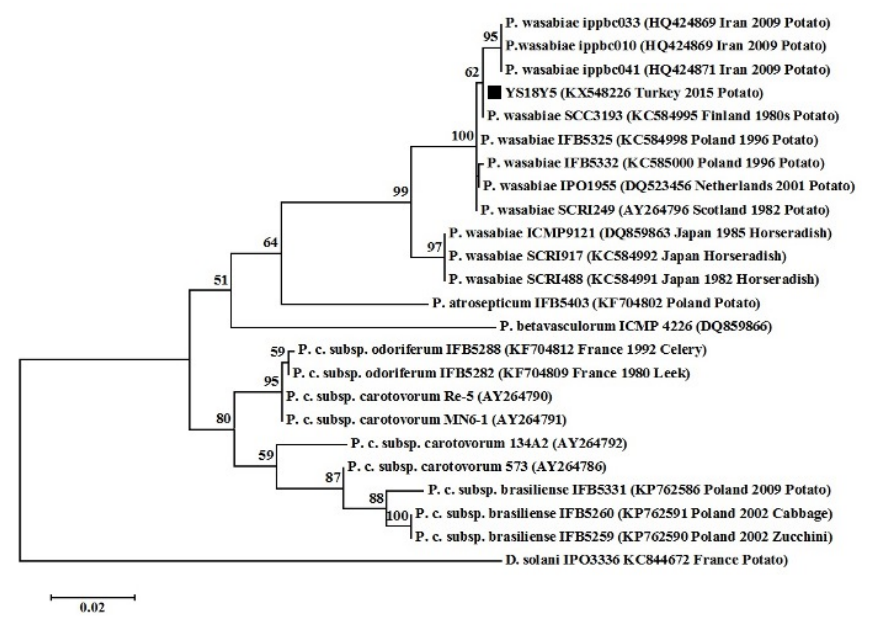

Figure 1

\section{Acknowledgements}

This work was supported by project grant from OMU-PYO. ZRT. 1901.15.011. and the National Science Centre, Poland UMO-2014/14/M/NZ8/00501. Thanks to TUBITAK BIDEB 2211-D Domestic Doctoral Fellowship Program.

\section{References}

Darrasse A, Priou S, Kotoujansky A, Bertheau Y, 1994. PCR and restriction fragment length polymorphism of a Pel gene as a tool to identify Erwinia carotovora in relation to potato diseases. Applied and Environmental Microbiology 60, 1437-1443.

De Boer SH, Li X, Ward LJ, 2012. Pectobacterium spp. associated with bacterial stem rot syndrome of potato in Canada. Phytopathology 102, 937-947. http://dx.doi.org/10.1094/PHYTO-04-12-0083-R

Frechon D, Exbrayat P, Helias V, et al., 1998. Evaluation of a PCR kit for the detection of Erwinia carotovora subsp. atroseptica on potato tubers. Potato Research 41, 163-73. http://dx.doi.org/10.1007/BF02358439

Kang HW, Kwon SW, Go SJ, 2003. PCR-based specific and sensitive detection of Pectobacterium carotovorum ssp. carotovorum by primers generated from a URP-PCR fingerprinting-derived polymorphic band. Plant Pathology 52, 127-133. http://dx.doi.org/10.1046/j.1365-3059.2003.00822.x

Potrykus M, Golanowska M, Sledz W, Zoledowska S, Motyka A, Kolodziejska A, Butrymowicz J, Lojkowska E, 2016. Biodiversity of Dickeya spp. isolated from potato plants and water sources in temperate climate. Plant Disease 100, 408-417.

http://dx.doi.org/10.1094/PDIS-04-15-0439-RE

Waleron M, Waleron K, Lojkowska E, 2013. Occurrence of Pectobacterium wasabiae in potato field samples. European Journal of Plant Pathology 137, 149-158. http://dx.doi.org/10.1007/s10658-013-0227-2

To cite this report: Ozturk M, Aksoy HM, Ozturk S, Potrykus M, Lojkowska E, 2016. First report of potato blackleg and soft rot caused by Pectobacterium wasabiae in Turkey. New Disease Reports 34, 17. http://dx.doi.org/10.5197/j.2044-0588.2016.034.017 